\title{
Development of Technological Pedagogical Content Knowledge (TPACK) for English Teachers: The Validity and Reliability
}

https://doi.org/10.3991/ijet.v14i20.11456

\author{
Noor Illi Binti Elas ( ${ }^{\varpi}$ ), Faizah Binti Abd Majid, Suthagar A/1 Narasuman \\ Universiti Teknologi MARA, Puncak Alam, Malaysia. \\ elas1963@yahoo.com
}

\begin{abstract}
This paper discusses a study proposed to analyze technology affecting English Language Teaching (ELT). To begin with, English is an important language in a society where it acts as a bridge to connect different races in a society. However, in the circumstance of 21 st-century education specifically for English Language Teaching (ELT) which has been affected by Industrial Revolution 4.0, technology plays an important part as it offers the potential to enhance teaching processes and facilitate the learning of English as Second Language (ESL). For this purpose, Technology Pedagogy Content Knowledge (TPACK) paves a way to determine the correlation between technology, pedagogy and content knowledge among the English teachers on how they incorporate these technology tools in their English teaching. Hence, because of this reason, English teachers will answer a TPACK questionnaire which was adapted from two different questionnaires to understand further how English teachers employ the technologies in ELT. Therefore, by holding on to this purpose, a questionnaire was adapted from two different major questionnaires that related to TPACK. As neighbour to the previous sentence, this research was about this adapted questionnaire that had gone through content validation by experts with more than 10 years of teaching experience in English subject. The methodology that had been used in this research was quantitative method. The data obtained was presented in the form of descriptive statistics and was analyzed by using Microsoft Excel to calculate the Content Value Index (CVI) and Kappa Values for validity. Also, the data was presented in the form of table as it can eliminate any incomprehensibility that arises in interpreting the data. Thus, as the result, the finding of this research had supported the face and content validity and this proved that the result had high reliability and validity. Hence, this adapted questionnaire will be further research in a pilot study to test the efficiency of this instrument.
\end{abstract}

Keywords-English Language Teaching; English Second Language; TPACK; Content Value Index; Kappa Value. 


\section{Introduction}

Education plays one of the most important roles in developing society. It is worth mentioning that English is generally used as a second language which is viewed as an important medium to communicate in different countries especially in Asia. Malaysia as one of the Asian countries has been focused on the importance of English Language in education. Alternately, Malaysia also undergoes Industrial Revolution 4.0 and this has given a tremendous impact on education specifically in the use of technologies; thus making integration of technologies a great requirement in teaching and learning. This, henceforth, defines $21^{\text {st }}$-century learning and teaching. Consequently, the significance of technology in education has been acknowledged as one of the important parts in the 10 shifts as outlined by the Malaysian government in National Education Blueprint (2015 - 2025). With this being outlined in the national education policy, English teachers are required to be well-equipped with the application of technology skills in order to deliver a competent teaching. This is supported by Chai, Koh, and Tsai (2010) who further asserted educators need to be self-equipped with knowledge and skills pertaining to technology and utilize them to produce more effective teaching and learning process. In return, this should help to reduce English Language Anxiety (ELA) among ESL learners.

English Language Anxiety (ELA) has been a kind of penumbra in English Language Learning as it can impact comprehension of English among ESL learners. In Malaysia, as stated by Latif (2015), even though the students have learned English for more than 10 years, they still face challenges in using the English language efficiently. Accordingly, Horwitz, Horwitz, and Cope (1986) expressed that second language learners often feel stressed, nervous and anxious in learning a second language. This is due to the fact that some of the learners will more than often encounter the "mental block" during the language learning process. This condition can happen to both beginner and advanced learners (Latif, 2015). This shows that anxiety may still hinder the learning process despite the complexity of the learning process and students' level of proficiency in the English language. There are many factors contributing to this problem and one of which is believed to originate from English teaching methodology especially when English teachers are unable to utilize technology to facilitate teaching in a classroom.

The integration of technology in classroom activities is thought to be a great facilitator in teaching and learning while the teachers still play a key role in this situation (Ramanair, Rethinasamy, \& Misieng, 2017). In the field of English Language Teaching (ELT), technologies offer plenty of benefits such as to widen vocabularies (Bytheway, 2015; Hitosugi, Schmidt, \& Hayashi, 2014; Ramanair et al., 2017; Wilkinson, 2015), encourage language output (Lockley \& Yoshida, 2016; Ramanair et al., 2017), promote language learning to share (Bikowski \& Vithanage, 2016; Dooly \& Sadler, 2016; Ramanair et al., 2017), adapt and create meaning within learning environment (Bikowski \& Vithanage, 2016; Dooly \& Sadler, 2016; Ramanair et al., 2017), and enhance grammar in writing (Feng, Saricaoglu, \& Chukharev-Hudilainen, 2016; Ramanair et al., 2017). This proves that by using technology tools in the classroom is important as it fulfil the necessity of a $21^{\text {st }}$-century learning environment. This 
is further supported by Kasim and Singh (2017) that professed technology offers opportunities for teachers to design different contexts and learning environment in the teaching and learning process to suit their learners' level of proficiency. Hence, it will indirectly make it easier for teachers to deliver lessons in the classroom and also to cater the needs of the students.

However, Kongi (2015) stated that modernity may bring along stress to learners despite their ability to cope with available technology outside the classroom. This may occur since most learners still face anxieties during traditional teaching and learning process, and inserting technology may add more pressure to them due to the methodology being recently developed (Balchin \& Wild, 2016). The existence of this situation may also be rooted in teachers' limited and unskilled use of technology (Sarhandi, Khan, Buledi, \& Asghar, 2016). Also, teachers' incompetency in use of technology and inadequacy of facilities in school to support the content of lessons have created obstruction for teachers to be able to manipulate technology tools in order to deliver competent teaching, especially in ELT.

Sahin (2011) stated that for a teacher to be successful in teaching, they need to selfdevelop the pedagogy, technology and their content areas individually as different teacher has different approaches in teaching. In this light of analysis, by integrating technology in the English classroom requires teachers to have knowledge about technology (Ramanair et al., 2017). This is so that teachers should be able to manipulate the technologies to create the suitable approaches to support the students' learning. When a teacher integrates technology into instructions, it allows students to participate in the subject (Sahin, 2011; Schrum et al., 2007; Sweeder \& Bednar, 2001). In contrast, if a teacher who is unable to utilize technology to deliver competent teaching to ESL learners of the current generation, this will likely to influence their anxiety level.

Therefore, it is important to find a way to integrate technologies in instructions to facilitate teaching by integrating technologies in instruction through investigating the reasons for deficiency in teachers' technology skills specifically in ELT. If there is a problem, surely there will be a way to overcome the problem. Hence, in this situation, even though a model to incorporate technology into curriculum seems to be a complex task for educators (Garofalo, Drier, Harper, Timmerman, \& Shockey, 2000; Hosseini \& Kamal, 2013), subsequently, Mishra and Koehler (2006) provided a Technological Pedagogy Content Knowledge (TPCK) framework to integrate technology into curriculum planning. As this pedagogy become crucial in ELT, Koehler and Mishra introduced an extended version of Technology Pedagogy Content Knowledge (TPACK). This was supported by Kasim and Singh (2017) who claimed this extended version of TPACK is especially necessary for ESL teachers to provide a proper learning environment for digitally students. For this purpose, Technology Pedagogy Content Knowledge (TPACK) is used as a way to determine the correlation between technology, pedagogy and content knowledge among English teachers and it is hoped to be able to overcome the problem that arise in using technological tools in ELT.

Mishra and Koehler (2006) defined Technology Pedagogy Content Knowledge (TPACK) as a basic concept of effective teaching that combining technology and pedagogical techniques in order to construct new apprehension from the existing 
knowledge among students. Archambault and Crippen (2009) also believed that TPACK involves a whole understanding of the complexity of relationship among students, teachers, contents, technologies, and practices. Hence, this brought Archambault and Crippen (2009) to produce a questionnaire that studies about this correlation in TPACK. From the other perspective, Nordin and Faekah (2016) defined TPACK as an understanding of the connection and interaction between technological knowledge, content knowledge and pedagogical knowledge in the learning process.

Therefore, through concepts gathered from literature related to teachers' knowledge about technology pedagogy and students' learning, this study is carried out based on the model inspired by Mishra and Koehler (2006) to organize teachers' knowledge and explore in depth about its relationship with students' understanding in English learning. In line with this, several studies have acknowledged the need to develop a more reliable and valid instrument to measure TPACK. Several TPACK surveys that were developed and tested on teachers in the United States had high internal reliability (Archambault \& Crippen, 2009; Schmidt et al., 2009). However, there is still a scarcity of researches about TPACK that focuses on English teachers in Malaysia. Also, there are several studies attempted to validate TPACK instrument in different contexts of study (Ersanli, 2016; Evens, Elen, \& Depaepe, 2015; Jang \& Tsai, 2012; Sahin, 2011). However, little had been done on English teachers especially for those who are used to traditional methods yet are forced to shift to modern methods as seemed to fit $21^{\text {st }}$-century learning and teaching.

With all these points are crossing together despite there are many studies carried out regarding TPACK in different contexts, this study employed to further learning and understand about the relationship of TPACK among English teachers. Since little researches of TPACK had been done among English teachers, this survey produced an adapted questionnaire that combines Schmidt et al. (2009) and Archambault and Crippen (2009)'s concepts. Thus, this research is hoped to be able to bridge the gap that exists in previous researches about TPACK in Malaysia. For that purpose, this study seeks to establish the reliability and validity of TPACK to further shed some light for more studies on TPACK among English teachers.

\section{$2 \quad$ Literature Review}

To begin with, Mishra and Koehler's (2006) formulation of the technological, pedagogical and content knowledge (TPACK) framework is an extended version of Shulman's (1986) categorizing teacher's knowledge about technology in effective teaching (Koehler, Mishra, Kereluik, Shin, \& Graham, 2014). Hence, TPACK's framework is as follows. 


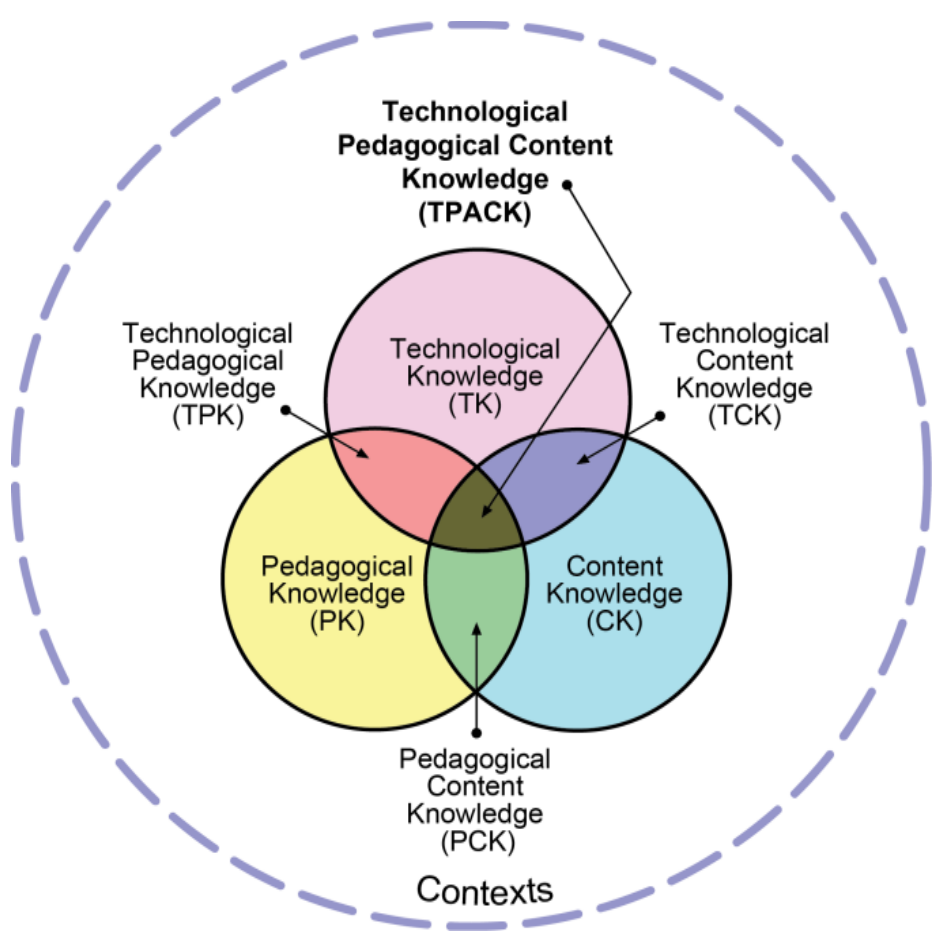

Fig. 1. Source: https://matt-koehler.com/tpack2/tpack-explained/

This framework has urged the need to develop and understand technological, pedagogical and content knowledge to effectively integrate technology in teaching. TPACK model focused on how these three domains can enhance the technological tools in ELT. The three domains are known as TK (Technological Knowledge), PK (Pedagogical Knowledge) and CK (Content Knowledge). A combination of TK, PK, and CK that form TPACK allows teachers to present the effective subject content to their learners by using the most suitable and available technology with the correct pedagogy (Mishra \& Koehler, 2006; Nordin \& Faekah, 2016). Specifically, the explanations about these three domains are explained in a detailed summary.

\subsection{Technological knowledge (TK)}

This domain refers to teachers' knowledge about traditional and new technologies that can be utilized in teaching and facilitate the learning among the learners as well (Koehler et al., 2014). 


\subsection{Pedagogical knowledge (PK)}

This domain focuses on the teachers' knowledge about wide and variety of instructional practices, strategies, and methods to facilitate students' learning in the classroom(Koehler et al., 2014).

\subsection{Content knowledge (CK)}

This domain related to any subject matter that focused on teachers' knowledge which required them to fully use the knowledge in teaching subjects at school (Koehler et al., 2014).

Since these domains are crossing each other, other four components were derived from these overlapping main domains which are known as TCK (Technological Content Knowledge), PCK (Pedagogical Content Knowledge), TPK (Technological Pedagogical Knowledge) and TPACK (Technological Pedagogical Content Knowledge), thus creating a fully developed model which is better-known as TPACK. Therefore, the explanations for the other four components are as following:

\subsection{Technological content knowledge (TCK)}

This component focuses on the knowledge related to the relationship between technology and content. In most situations, disciplinary knowledge is often defined and limited by technologies and their functions in teaching (Koehler et al., 2014).

\subsection{Pedagogical content knowledge (PCK)}

This component referred to Shulman's (1986) point of "an understanding of how particular topics, problems or issues are organized, represented and adapted to the diverse interests and abilities of learners, and presented as instructions" (p.8) (Koehler et al., 2014).

\subsection{Technological pedagogical knowledge (TPK)}

This component relates to the perception of technology which can be helpful or in another way, limiting the specific pedagogical in teaching (Koehler et al., 2014).

\subsection{Technological pedagogical content knowledge (TPACK)}

This component writes about the knowledge that related to the complex relations among the technology, pedagogy, and content which will help teachers to create a proper and content-specific teaching approaches in the classroom (Koehler et al., 2014).

TPACK allows teachers to have a deep understanding about each domain and components of this framework as it can facilitate teachers to coordinate, manipulate and orchestrate technology, pedagogy, and content into a teaching method, especially 
in ELT. A further point that needs to be noted is that TPACK is a form of knowledge that exists in an impulsive amalgam of traditional and modern technologies. This will facilitate the ELT, especially in $21^{\text {st }}$-century teaching and learning. As stated by Köse (2016), it is important to expose the perceptions of the language teachers' selfefficacy in integrating the technology into language teaching in order to create effective and successful language learning and teaching. This is because, teachers have different pedagogical that suit the learners' need in learning. Also, the factors that hinder technology integration should be studied further in order to help teachers to overcome problems when it comes to combine technology and their teaching methods to enhance ELT.

\section{Methodology / Materials}

\subsection{Development of instrument}

In this research, TPACK is not just a framework created to understand and justify teachers' use of technology in the classroom. It is also used to study the level of comprehension about the importance of technologies to be integrated into teaching content. Hence, by noticing how important TPACK in ELT is, there are various approaches and different theories that employ technologies in teaching. Because of this reason, researchers are continuously seeking for a new and suitable prospect to combine technologies and knowledge into effective teaching. This happened as technologies will keep on progressing and changing prior to the change of time and era. Also, there are other researchers that came out with different instruments to study TPACK (Archambault \& Crippen, 2009; Schmidt et al., 2009). Hence, in view of this research, an adapted questionnaire that combined both Schmidt et al. (2009) and Archambault and Crippen (2009) is developed as shown below.

Table 1. The Component of TPACK

\begin{tabular}{|c|c|c|}
\hline Items & Question & Sources \\
\hline \multicolumn{3}{|c|}{ TK (Technology Knowledge) } \\
\hline B1 & I know how to solve my own technical problems. & Schmidt et al. (2009) \\
\hline $\mathrm{B} 2$ & I can learn about technology easily. & Schmidt et al. (2009) \\
\hline B3 & I keep up with important new technologies. & Schmidt et al. (2009) \\
\hline B4 & I frequently play around with technology. & Schmidt et al. (2009) \\
\hline B5 & I know about a lot of different technologies. & Schmidt et al. (2009) \\
\hline B6 & I have the technical skills I need to use technology & Schmidt et al. (2009) \\
\hline B7 & $\begin{array}{l}\text { I have had sufficient opportunities to work with different technol- } \\
\text { ogies }\end{array}$ & Schmidt et al. (2009) \\
\hline \multicolumn{3}{|c|}{ CK $($ Content Knowledge $)$} \\
\hline B8 & I have sufficient knowledge about English & Schmidt et al. (2009) \\
\hline B9 & $\begin{array}{l}\text { I have various ways and strategies for developing my understand- } \\
\text { ing of English }\end{array}$ & Schmidt et al. (2009) \\
\hline $\mathrm{B} 10$ & $\begin{array}{l}\text { I can create materials that map to a specific level of proficiency } \\
\text { among my students in teaching English. }\end{array}$ & $\begin{array}{l}\text { Archambault and Crippen } \\
(2009)\end{array}$ \\
\hline B11 & I can decide on the scope of concepts taught within my class. & Archambault and Crippen \\
\hline
\end{tabular}




\begin{tabular}{|c|c|c|}
\hline & & $(2009)$ \\
\hline \multicolumn{3}{|c|}{ PK (Pedagogical Knowledge) } \\
\hline B12 & I know how to asses student performance in a classroom & Schmidt et al. (2009) \\
\hline B13 & $\begin{array}{l}\text { I can adapt my teaching based upon what students currently } \\
\text { understand or do not understand. }\end{array}$ & Schmidt et al. (2009) \\
\hline B14 & I can adapt my teaching style to different learners. & Schmidt et al. (2009) \\
\hline B15 & I can assess student learning in multiple ways in my class. & Schmidt et al. (2009) \\
\hline B16 & $\begin{array}{l}\text { I can use a wide range of teaching approaches in a classroom } \\
\text { setting }\end{array}$ & Schmidt et al. (2009) \\
\hline B17 & $\begin{array}{l}\text { I am familiar with common student understandings and miscon- } \\
\text { ceptions }\end{array}$ & Schmidt et al. (2009) \\
\hline B18 & I know how to organize and maintain classroom management. & Schmidt et al. (2009) \\
\hline \multicolumn{3}{|c|}{ PCK (Pedagogical Content Knowledge $)$} \\
\hline B19 & $\begin{array}{l}\text { I can select effective teaching approaches to guide students' } \\
\text { thinking and learning in English. }\end{array}$ & Schmidt et al. (2009) \\
\hline B20 & I can produce lesson plans based on the topic in English & $\begin{array}{l}\text { Archambault and Crippen } \\
(2009)\end{array}$ \\
\hline \multicolumn{3}{|c|}{ TCK (Technological Content Knowledge) } \\
\hline B21 & $\begin{array}{l}\text { I know about technologies that I can use for teaching specific } \\
\text { concepts in English. }\end{array}$ & Schmidt et al. (2009) \\
\hline B22 & I know about the technologies that I can use for teaching English. & $\begin{array}{l}\text { Archambault and Crippen } \\
(2009)\end{array}$ \\
\hline \multicolumn{3}{|c|}{ TPK (Technological Pedagogical Knowledge) } \\
\hline B23 & $\begin{array}{l}\text { I can choose technologies that enhance the teaching approaches } \\
\text { for a lesson. }\end{array}$ & Schmidt et al. (2009) \\
\hline B24 & $\begin{array}{l}\text { I can choose technologies that enhance students' learning for a } \\
\text { lesson. }\end{array}$ & Schmidt et al. (2009) \\
\hline B25 & $\begin{array}{l}\text { I am thinking critically about how to use technology in my class- } \\
\text { room. }\end{array}$ & Schmidt et al. (2009) \\
\hline B26 & $\begin{array}{l}\text { I can adapt to the use of the technologies that I am learning about } \\
\text { different teaching activities. }\end{array}$ & Schmidt et al. (2009) \\
\hline $\mathrm{B} 27$ & I can encourage online interactivity among students in my class. & $\begin{array}{l}\text { Archambault and Crippen } \\
(2009)\end{array}$ \\
\hline \multicolumn{3}{|c|}{ TPACK (Technological Pedagogy Content Knowledge) } \\
\hline B28 & $\begin{array}{l}\text { I can teach lessons that appropriately combine English, technolo- } \\
\text { gies and teaching approaches. }\end{array}$ & Schmidt et al. (2009) \\
\hline B29 & $\begin{array}{l}\text { I can select technologies to use in my classroom that enhance } \\
\text { what I teach, how I teach and what students learn. }\end{array}$ & Schmidt et al. (2009) \\
\hline B30 & $\begin{array}{l}\text { I can use strategies that combine content, technologies and teach- } \\
\text { ing approaches that I know. }\end{array}$ & Schmidt et al. (2009) \\
\hline B31 & $\begin{array}{l}\text { I can provide leadership in helping others to coordinate the use of } \\
\text { content, technologies and teaching approaches at my school. }\end{array}$ & Schmidt et al. (2009) \\
\hline B32 & $\begin{array}{l}\text { I can provide leadership in helping others to coordinate the use of } \\
\text { content, technologies and teaching approaches at my district. }\end{array}$ & Schmidt et al. (2009) \\
\hline B33 & I can choose technologies that enhance the content for a lesson. & Schmidt et al. (2009) \\
\hline B34 & $\begin{array}{l}\text { I can use technology to predict students' skill in a particular topic } \\
\text { in English subject. }\end{array}$ & $\begin{array}{l}\text { Archambault and Crippen } \\
(2009)\end{array}$ \\
\hline B35 & $\begin{array}{l}\text { I can use technology to predict students' understanding of a } \\
\text { particular topic in English }\end{array}$ & $\begin{array}{l}\text { Archambault and Crippen } \\
(2009)\end{array}$ \\
\hline
\end{tabular}




\subsection{Instrument validation}

Before an adapted or a developed questionnaire is used to conduct the pilot study, the questionnaire had to go through validity and reliability tests. Reliability and validity of the instrument is an important analysis which it can be used to consider the effectiveness of the instrument used (Kaplan \& Saccuzzo, 2005; McIntire \& Miller, 2007). Hence, for the purpose of this research, validity is necessary to study how established questionnaire which tallies with the research objectives.

Teaching evaluation becomes crucial in pedagogy field especially when it comes to $21^{\text {st }}$ century teaching and learning. Therefore, numerous researches are indeed important to assess teaching effectiveness related to utilizing technologies tool. Thus, there is a demand to have a validated, reliable and comparable presentation of data for the sake of improving teaching quality. Because of this reason, this study is aimed to examine the validity and reliability of TPACK that will be administered among English teachers. In addition, this study is also intended to explore further statistical analytic thinking to validate TPACK among English teachers.

As stated by Nordin and Faekah (2016), TPACK questionnaire was developed in the USA and has not been tested in a Malaysian education setting. Hence, due to that reason, the questionnaire in this research will be brought to the next step which is through the validity test. Therefore, the validity tests that are used were face validity and content validity. The researcher distributed this questionnaire to five teachers who are experts and well-adapted in English learning methodologies. They have also attended a special workshop about $21^{\text {st }}$-century learning and teaching organized by Ministry of Education. The instrument was self-distributed to the panel of experts complete with the official letter issued by Faculty of Education, UiTM Puncak Alam.

The questionnaire contained 35 items which were divided into seven components that question about technology's knowledge, content, pedagogy and how English teachers integrate the technologies into the ELT. This test instrument would be based on numerous opinions from these experts based on their professional ethics and teaching experiences (Sangoseni, Hellman, \& Hill, 2013). Hence, the comments and suggestions from the pane lists are welcomed in this research. For the face validity, it is necessary to have a guideline to avoid any incomprehensible and vague data. Therefore, Oluwatayo (2012)'s proposals were used to evaluate the face validity of this questionnaire as listed below:

- Appropriateness of grammar.

- The clarity and unambiguous of items.

- The correct spelling of words.

- The correct structuring of the sentences.

- Appropriateness of font size.

- The structure of the instrument in terms of construction and flow of the format.

The validity used to calculate the inter-rater reliability was calculated by using Cohen's Kappa. Two of the pane lists were asked to answer "YES" or "NO" for all 35 items. This is necessary to demonstrate the degree of the data collected in the study. 
The data collected will be studied whether it represents the variables measured in research (McHugh, 2012).

From other perspectives, Content Value Index (CVI) was used to study the content validity in this research. As stated by Lynn (1986), CVI is about the number of agreement from the pane lists in examining research validity. It depends on the number of pane lists involved in the research as there might be less than three pane lists and more than five pane lists. Lynn (1986) further advised that panel experts should be a minimum of three experts yet if it is probably unnecessary to have more than 10 . Therefore, for this research, five pane lists were selected to participate in this research due to convenience purpose and time limitation.

Nonetheless, some researchers never demonstrate their calculation for CVI in content validity. This was supported by Polit and Beck (2006) who stated authors of scale development papers almost never demonstrate the methods they used to compute SCVI. Thus, the result must be shown in a table to clarify any uncertainty raised from the research. The table is considered a great alternative to explain the method used to calculate S-CVI. Hence, by going through this study, a great CVI index of 1 should be achieved as it reflects all of the pane lists agreeing with the items (80\% or 0.8 to represent a high-level agreement) (Sangoseni et al., 2013). On the other hand, a low CVI of less than $80 \%$ reflects the items as unable to reach the objectives proposed in the research.

\section{$4 \quad$ Results and Findings}

In light of this analysis, all panel members are academicians who work as English teachers for the secondary schools. Their number of years in practice ranged from 15 years to 35 years. Therefore, the average years of teaching experience for all panelists are about 25 years. This period of time should be considered as adequate for them to study technology's knowledge since they are used to both traditional and modern methods. The reason lies in $21^{\text {st }}$-century learning and teachings being introduced in the year of 2014: the year when teachers are encouraged to fully utilize technologies in teaching.

Hence, for face validity, a suggestion proposed by the experts "to split the doublebarrel questions" in ensuring validation for this questionnaire. Although the suggestion "to split the double-barrel questions" does not exist in the list proposed by Oluwatayo (2012), it was important for the researcher to consider for this questionnaire as it will be able to avoid double meanings in one sentence. Also, this suggestion is indeed important for the researcher to make sure that the essence of this questionnaire is preserved in this research. This is also helpful for the researcher to come out with the items that directly question what is needed to be asked about TPACK in this adapted questionnaire. All of the comments and suggestions by the panel experts are as shown in Table 2. 
Table 2. The Correction and Suggestion by Panel Experts

\begin{tabular}{|l|l|}
\hline \multicolumn{1}{|c|}{ Comments } & \multicolumn{1}{c|}{ Panels } \\
\hline Grammar correction & $1,2,3,4$ and 5 \\
\hline The clarity and unambiguous of questions & none \\
\hline The correct spelling of words & none \\
\hline The correct structuring the sentence & none \\
\hline Appropriateness of font size & none \\
\hline The structure of the questions & none \\
\hline Split the double-barrel questions & 1,3 and 4 \\
\hline
\end{tabular}

On the other hand, the result for calculation of inter-rater reliability had yielded the result presenting the percentage of inter-rater agreement was $88 \%$ (Kappa value $=$ $0.88, \mathrm{p}=0.000<0.005)$ which is considered as strong (McHugh, 2012). The data received proved that the items in this questionnaire are already valid within this validity test. For content validity, all 35 items were analyzed by the content experts. Hence, the sentence structure for B3, B6, B9, B11, B15, B16, B18, B20, B26, B30, $\mathrm{B} 32$ were corrected by the researcher based on the comments and suggestions received from the pane lists. As a result, the CVI for each item is represented in Table 3 as follows.

Table 3. The Number of Agreements by Panel Experts and the Calculation of CVI

\begin{tabular}{|c|c|c|c|c|c|}
\hline Item & Panel Expert & CVI & Item & Panel Expert & CVI \\
\hline B1 & 5 & 1 & B19 & 5 & 1 \\
\hline B2 & 5 & 1 & B20 & 4 & 0.8 \\
\hline B3 & 4 & 0.8 & B21 & 5 & 1 \\
\hline B4 & 5 & 1 & B22 & 5 & 1 \\
\hline B5 & 5 & 1 & B23 & 5 & 1 \\
\hline B6 & 4 & 0.8 & B24 & 5 & 1 \\
\hline B7 & 5 & 1 & B25 & 5 & 0.8 \\
\hline B8 & 5 & 1 & B26 & 4 & 1 \\
\hline B9 & 4 & 0.8 & B27 & 5 & 1 \\
\hline B10 & 5 & 1 & B28 & 5 & 1 \\
\hline B11 & 4 & 0.8 & B29 & 5 & 0.8 \\
\hline B12 & 5 & 1 & B30 & 4 & 1 \\
\hline B13 & 5 & 1 & B31 & 5 & 0.8 \\
\hline B14 & 5 & 1 & B32 & 4 & 1 \\
\hline B15 & 4 & 0.8 & B33 & 5 & 1 \\
\hline B16 & 4 & 0.8 & B34 & 5 & 1 \\
\hline B17 & 5 & 1 & B35 & 5 & \\
\hline B18 & 4 & 0.8 & & & \\
\cline { 1 - 4 } & & & & & \\
\cline { 1 - 4 } & 5 & 5 & & 5 & 1 \\
\hline
\end{tabular}

\section{Discussion}

For Face Validity, Oluwatayo (2012) proposed five notions or criteria that have to be fulfilled in research. As stated in Table (1), all the pane list agree with the first statement "Grammar correction" which specifically means that the sentences must 
be changed to present tense. As stated by panel 1 and panel 2, this is due to the items are investigating the current occurrences among teachers, not happened in the past. Aside from that, none of the pane lists commented on "The clarity and unambiguity of questions". This is because the items are adapted questions from a well-established questionnaire by Schmidt et al. (2009) and Archambault and Crippen (2009). So, the purpose of these items is well delivered in each of the statements. For the third and fourth items which are "The correct spelling of words" and "The correct structuring of the sentence" received no comments from the pane lists as the questionnaire had been proofread by the researcher's supervisor who happens to be an English lecturer, ranked as an Associate Professor. For "the appropriateness of font size", the researcher used Times New Roman and size 14 for the questionnaire to eliminate any technical doubts emerging from this research. For "the structure of the questions", none of the pane lists commented on this part either. It is believed that since the items were adapted from an established questionnaire and had been proofread, the structure of the questions remained in established sentences. However, for "split the double barrel questions", there are pane lists (Panel 1, Panel 3 and Panel 4) asked the items to be separated into two items and avoid using the conjunction "and" in one item. The reason is due to it might create two different meanings in one item which leads to ambiguity within the items.

From other perspectives, the inter-rater reliability was calculated using Cohen's Kappa Index. Even though there are many methods to calculate inter-rater reliability such as Fleiss's Kappa and IRR, Cohen's Kappa was used for this research as it is more convenient and requires a shorter time. Cohen's Kappa was employed because only two raters are needed compared to Fleiss's Kappa that needs three or more pane lists. Since all of the items are adapted items from two different questionnaires, Cohen's Kappa produced was 0.88 and considered strong (McHugh, 2012). Hence, this questionnaire may be used in the research later.

As for the Content Validity Index (CVI), pane lists' approval was indeed important to study the degree of the correct items that correspond with the purpose of the research. Indeed, Content Validity Index used in this study actually did not focus on the level of agreement because CVI measures the proportion of agreement among a group of experts. This was supported by Masuwai, Tajudin, and Saad (2016) that stated CVI focuses more on the quotient of agreement by the pane list rather than the level of agreement. This allows CVI to be very useful in eliminating any uncertainty and permits direct interpretation which helps in building more dependable and logical data about the content validity. All the items that were maintained from the original version are considered relevant to the thematic domains based on high CVI produced in this validity test. Obviously, all the comments and corrections recommended by the panels were well thought out for revisions (Masuwai et al., 2016). Therefore, the items of this questionnaire were concluded in the table as follows: 
Table 4. The Finalize Components of TPACK

\begin{tabular}{|c|l|c|l|}
\hline Theme & \multicolumn{1}{|c|}{ Components } & Total Items & \multicolumn{1}{|c|}{ Items Number } \\
\hline 1 & TK (Technology Knowledge) & 7 items & B1, B2, B3, B4, B5, B6, B7 \\
\hline 2 & CK (Content Knowledge) & 4 items & B8, B9, B10, B11 \\
\hline 3 & PK (Pedagogical Knowledge) & 7 items & B12, B13, B14, B15, B16, B17, B18 \\
\hline 4 & PCK (Pedagogical Content Knowledge) & 2 items & B19, B20 \\
\hline 5 & TCK (Technological Content Knowledge) & 2 items & B21, B22 \\
\hline 6 & TPK (Technological Pedagogical Knowledge) & 5 items & B23, B24, B25, B26, B27 \\
\hline 7 & $\begin{array}{l}\text { TPACK (Technological Pedagogy Content } \\
\text { Knowledge) }\end{array}$ & 8 items & $\begin{array}{l}\text { B28, B29, B30, B31, B32, B33, } \\
\text { B34, B35 }\end{array}$ \\
\hline & Total & 35 items & \\
\hline
\end{tabular}

\section{Conclusion}

This new instrument which combined two questionnaires is found to establish an adequate and acceptable measurement of performance which will be needed for future descriptive studies on how technology can affect ELT among English teachers. The validity test used in this research has proven that this adapted questionnaire has adequate face and content validity and thus, can be further used for the next study.

\section{$7 \quad$ Acknowledgements}

I thank God for giving me the opportunity to embark on this journey in completing this long and challenging process successfully. I would like to express my deepest gratitude to my respected project advisor, Prof. Dr. Faizah Abd Majid, and my cosupervisor, Associate Prof. Dr. Suthagar A/L Narasuman, whom have provided me with a significant contribution through continuous guidance, comments, suggestions, knowledge and untiring supervision in preparing this research successfully. Truth to be told, this research would have been impossible without their guidance. Also, I would like to extend my gratitude to the panel experts participating in this study for sharing valuable information and suggestions to allow this research to be carried out significantly. Furthermore, no words can express how grateful I am to my family for the unconditional love and continuous encouragement to complete this journey. Special gratitude is also dedicated to my friends for contributing ideas, giving suggestions and sharing the information and meaningful ideas in preparing my paper. Last but not least, to any individuals who have supported, helped and worked with me throughout my journey, I thank you from the bottom of my heart.

\section{References}

[1] Archambault, L., \& Crippen, K. (2009). Examining TPACK Among K-12 Online Distance Educators in the United States. Contemporary Issues in Technology and Teacher Education, $9(1)$. 
[2] Balchin, K., \& Wild, C. (2016). Exploring the Role of Recently-Qualified English Teachers in Developing Technology Use in Language Classrooms Through Communities of Practice. ELT Research Papers 16.05, 1-22.

[3] Bikowski, D., \& Vithanage, R. (2016). Effects of Web-Based Collaborative Writing on Individual L2 Writing Development. Language Learning and Technology, 20(1), 79-99.

[4] Bytheway, J. (2015). A Taxonomy of Vocabulary Learning Strategies Used in Massively Multiplayer Online Role-Playing Games. CALICO Journal, 32(3), 508-527. https://doi.org/ 10.1558/cj.v32i3.26787

[5] Chai, C., Koh, J., \& Tsai, C.-C. (2010). Facilitating Preservice Teachers' Development of Technological, Pedagogical, and Content Knowledge (TPACK). Educational Technology \& Society, 13(4), 63-73.

[6] Dooly, M., \& Sadler, R. (2016). Becoming Little Scientists: Technologically-Enhanced Project-Based Language Learning. Language Learning and Technology, 20(1), 54-78.

[7] Ersanli, C. Y. (2016). Improving Technological Pedagogical Content Knowledge (TPACK) of Pre-Service English Language Teachers International Education Studies, 9(5), 18-27. https://doi.org/10.5539/ies.v9n5p18

[8] Evens, M., Elen, J., \& Depaepe, F. (2015). Developing Pedagogical Content Knowledge: Lessons Learned from Intervention Studies. Education Research International, 2015(Article ID 790417), 1-23. https://doi.org/10.1155/2015/790417

[9] Feng, H.-H., Saricaoglu, A., \& Chukharev-Hudilainen, E. (2016). Automated Error Detection for Developing Grammar Proficiency of ESL Learners. CALICO Journal, 33(1), 4970. https://doi.org/10.1558/cj.v33i1.26507

[10] Garofalo, J., Drier, H. S., Harper, S., Timmerman, M. A., \& Shockey, T. (2000). Promoting Appropriate Uses of Technology in Mathematics Teacher Preparation. Contemporary Issues in Technology and Teacher Education, 1(1).

[11] Hitosugi, C. I., Schmidt, M., \& Hayashi, K. (2014). Digital Game-Based Learning (DGBL) in the L2 Classroom: The Impact of the UN's Off-the-Shelf Videogame, Food Force, on Learner Affect and Vocabulary Retention. CALICO Journal, 31(1), 19-39. https://doi.org /10.11139/cj.31.1.19-39

[12] Horwitz, E. K., Horwitz, M. B., \& Cope, J. (1986). Foreign Language Classroom Anxiety. The Modern Language Journal, 70(2), 125-132. https://doi.org/10.1111/j.1540-4781.1986. tb05256.x

[13] Hosseini, Z., \& Kamal, A. (2013). A Survey on Pre-Service and In-Service Teachers' Perceptions of Technological Pedagogical Content Knowledge (TPCK). Malaysian Online Journal of Educational Technology, 1(2), 1-7.

[14] Jang, S.-J., \& Tsai, M.-F. (2012). Exploring the TPACK of Taiwanese Elementary Mathematics and Science Teachers With Respect to Use of Interactive Whiteboards. Computers \& Education, 59(2), 327-338. https://doi.org/10.1016/j.compedu.2012.02.003

[15] Kaplan, R. M., \& Saccuzzo, D. P. (2005). Psychological Testing: Principles, Applications, and Issues, 5th ed. Belmont, CA, US: Wadsworth/Thomson Learning.

[16] Kasim, M. Z. M., \& Singh, C. K. S. (2017). A Review of Research on Pre-Service Teachers' Technological Pedagogical Content Knowledge for Teaching English Language. International Journal of Academic Research in Business and Social Sciences, 7(10), 436-448. https://doi.org/10.6007/ijarbss/v7-i10/3391

[17] Koehler, M. J., Mishra, P., Kereluik, K., Shin, T. S., \& Graham, C. R. (2014). The Technological Pedagogical Content Knowledge Framework. In J. M. Spector, M. D. Merrill, J. Elen, \& M. J. Bishop (Eds.), Handbook of Research on Educational Communications and Technology (4th ed., pp. 101-111). New York: Springer. https://doi.org/10.1007/978-1-46 $\underline{14-3185-5 \quad 9}$ 
[18] Kongi, M. (2015). Reducing Anxiety in English Language Class. Unpublished thesis. University of Tartu. Retrieved from http://dspace.ut.ee/bitstream/handle/10062/47066/Mari\% 20Kongi_MA.pdf

[19] Köse, N. K. (2016). Technologiclal Pedagogical Content Knowledge (TPACK) of English Language Instructors. Journal of Educational and Instructional Studies, 6(2), 12-19.

[20] Latif, N. A. A. (2015). A Study on English Language Anxiety among Adult Learners in Universiti Teknologi Malaysia (UTM). 208, 223-232. https://doi.org/10.1016/j.sbspro.20 $\underline{15.11 .198}$

[21] Lockley, T., \& Yoshida, C. (2016). Language and Culture Exchange in Foreign Language Learning: An Experiment and Recommendations. Innovation in Language Learning and Teaching, 10(3), 238-254. https://doi.org/10.1080/17501229.2014.960419

[22] Lynn, M. R. (1986). Determination and Quantification Of Content Validity. Nursing Research, 35(6), 382-386.

[23] Masuwai, A., Tajudin, N. a. M., \& Saad, N. S. (2016). Evaluating the Face and Content Validity of A Teaching and Learning Guiding Principles Instrument (TLGPI): A Perspective Study of Malaysian Teacher Educators. Geografia : Malaysian Journal of Society and Space, 12(3), 11-21. https://doi.org/10.1063/1.4983911

[24] McHugh, M. L. (2012). Interrater Reliability: The Kappa Statistic. Biochem Med (Zagreb), 22(3), 276-282. https://doi.org/10.11613/bm.2012.031

[25] McIntire, S. A., \& Miller, L. A. (2007). Foundations of Psychological Testing: A Practical Approach, 2nd ed. Thousand Oaks, CA, US: Sage Publications, Inc.

[26] Mishra, P., \& Koehler, M. J. (2006). Technological Pedagogical Content Knowledge: A New Framework for Teacher Knowledge. Teachers College Record, 108(6), 1017-1054. https://doi.org/10.1111/j.1467-9620.2006.00684.x

[27] Nordin, H., \& Faekah, T. A. T. (2016). Validation of a Technological Pedagogical Content Knowledge Instrument in a Malaysian Secondary School Context. Malaysian Journal of Learning and Instruction, 13(1), 1-24. https://doi.org/10.32890/mjli2016.13.1.1

[28] Oluwatayo, J. A. (2012). Validity and Reliability Issues in Educational Research Journal of Educational and Social Research, 2(2), 391-400.

[29] Polit, D. F., \& Beck, C. T. (2006). The Content Validity Index: Are You Sure You Know What's being Reported? Critique and Recommendations. Research in Nursing \& Health, 29(5), 489-497. https://doi.org/10.1002/nur.20147

[30] Ramanair, J., Rethinasamy, S., \& Misieng, J. (2017). The Technological, Pedagogical and Content Knowledge (TPACK) of Tertiary Level English Language Instructors in Integrating Technology in Language Classrooms. E-Proceeding of the 6th Global Summit on Education 2017.

[31] Sahin, I. (2011). Development of Survey of Technological Pedagogical and Content Knowledge (TPACK). Turkish Online Journal of Educational Technology (TOJET), 10(1), 97-105.

[32] Sangoseni, O., Hellman, M., \& Hill, C. (2013). Development and Validation of a Questionnaire to Assess the Effect of Online Learning on Behaviors, Attitudes, and Clinical Practices of Physical Therapists in the United States Regarding Evidenced-based Clinical Practice. The Internet Journal of Allied Health Sciences and Practice, 11(2), 1-12.

[33] Sarhandi, P. S., Khan, I. F., Buledi, M. H., \& Asghar, J. (2016). Integration of Technology with Pedagogical Perspectives: An Evaluative Study of In-House Call Professional Development. Arab World English Journal (AWEJ), Special Issue on CALL(3), 22-35. https://doi.org/10.2139/ssrn.2822975

[34] Schmidt, D. A., Baran, E., Thompson, A. D., Mishra, P., koehler, M. J., \& Shin, T. S. (2009). Technological Pedagogical Content Knowledge (TPACK): The Development and 
Validation of an Assessment Instrument for Preservice Teachers. Journal of Research on Technology in Education, 42(2), 123-149. https://doi.org/10.1080/15391523.2009.107825 $\underline{44}$

[35] Schrum, L., Thompson, A., Maddux, C., Sprague, D., Bull, G., \& Bell, L. (2007). Editorial: Research on the Effectiveness of Technology in Schools: The Roles of Pedagogy and Content. Contemporary Issues in Technology and Teacher Education, 7(1), 456-460.

[36] Shulman, L. S. (1986). Those Who Understand: Knowledge Growth in Teaching. Educational Researchers, 15(2), 4-14.

[37] Sweeder, J., \& Bednar, M. R. (2001). "Flying” with Educational Technology. Contemporary Issues in Technology and Teacher Education, 1(3), 421-428.

[38] Wilkinson, D. (2015). English-Medium Content Courses: Student Approaches and Strategies to Increase Comprehension Levels. International Journal of Learning, Teaching and Educational Research, 11(3), 1-16.

\section{Authors}

Noor Illi Binti Elas, Faizah Binti Abd Majid \& Suthagar A/l Narasuman works at the Faculty of Education in Universiti Teknologi MARA, UiTM Puncak Alam Campus, Puncak Alam, Selangor, Malaysia.

Article submitted 2019-06-23. Resubmitted 2019-08-17. Final acceptance 2019-08-18. Final version published as submitted by the authors. 